\title{
KONSTRUKSI PERTANGGUNG JAWABAN PIDANA LAKI-LAKI ATAS PERBUATAN MENELANTARKAN PEREMPUAN DAN ANAK DI LUAR KAWIN
}

\author{
Nahdiya Sabrina \\ Fakultas Hukum Universitas Merdeka Malang \\ Jl. Terusan Raya Dieng No. 62-64 Malang \\ nahdiya.sabrina@unmer.ac.id
}

\begin{abstract}
The act of a man releasing responsibility for a woman's pregnancy outside of marriage is an act that deemed deplorable in society, and of course bring harm to women and children. But until this moment there is no rule that can be used in ensure the perpetrator or to force him to account for the act. By not regulating this act the state would surely let this act continue so that more and more children become victims. Whereas this act is contrary to the mandate of law no. 35 year 2014 regarding the amandement to the law no 23 year 2002 on child protection.
\end{abstract}

Keywords: Criminal Liability, Outside Marriage Relationship.

\begin{abstract}
ABSTRAK
Perbuatan laki-laki melepaskan tanggungjawabnya atas kehamilan perempuan di luar kawin adalah merupakan perbuatan yang dianggap tercela dalam masyarakat, dan tentu saja membawa kerugian bagi wanita dan anak. Namun sampai saat ini tidak ada peraturan yang bisa dipakai dalam menjerat pelaku atau untuk mengadakan pemaksaan kepada pelaku guna mempertanggungjawabkan perbuatannya. Dengan tidak diaturnya perbuatan ini, negara tentu saja membiarkan perbuatan ini terus menerus terjadi sehingga semakin banyak anak yang menjadi korban. Padahal perbuatan ini sangat bertentangan dengan amanat Undang-Undang Republik Indonesia Nomor 35 tahun 2014 Tentang Perubahan atas Undang-Undang Nomor 23 Tahun 2002 Tentang Perlindungan Anak.
\end{abstract}

Kata Kunci: Hubungan Luar Kawin, Pertanggungjawaban Pidana.

Menurut data yang diperoleh BKKBN, sebanyak 20,9 persen remaja di Indonesia mengalami kehamilan dan kelahiran sebelum menikah, tentu angka ini merupakan angka yang terbilang tinggi dan memprihatinkan. Sekitar $62,7 \%$ remaja di Indonesia telah melakukan hubungan seks di luar nikah, 20\% dari 94.270 perempuan yang mengalami hamil di luar nikah juga berasal dari kelom- pok usia remaja dan $21 \%$ diantaranya pernah melakukan aborsi (Anonim, 2016).

Tingginya angka tersebut menyisakan banyak masalah yang pada akhirnya merugikan wanita itu sendiri dan anak yang sedang dikandungnya. Salah satu masalah yang mungkin terjadi adalah keengganan pihak laki-laki untuk bertanggungjawab atas kehamilan yang di alami wanita tersebut. 
Seperti sebuah kasus yang terjadi di Palembang, Yazid (22 tahun) kabur dan tidak mau bertanggungjawab setelah pacarnya Rena (20 tahun) hamil, alasan pria tersebut adalah karena tidak memiliki uang untuk biaya menikah. Perbuatan ini membuat keluarga korban melaporkan Yazid ke Polresta Palembang (Welly Hadinata, 2015).

Namun dari laporan tersebut sudah pasti bisa ditebak, penyidik tidak akan bisa memproses lebih lanjut kasus yang bersangkutan, karena perbuatan laki-laki yang tidak bertanggung jawab atas hamilnya perempuan luar kawin tidak diatur dalam undang-undang manapun. Artinya persoalan ini hanya dapat diselesaikan melalui jalur kekeluargaan, kalaupun si laki-laki menolak untuk bertanggung jawab tidak ada sanksi pidana yang bisa menjeratnya. Dan tidak ada aturan yang dapat memaksa laki-laki tersebut untuk memenuhi tanggung jawabnya.

Para ayah yang tidak bertanggung jawab ini nantinya akan mempunyai andil dalam buruknya perkembangan anak. Sebuah laporan dari Departemen Kesehatan dan Layanan Masyarakat AS menyatakan, "Anak-anak kecil yang dibesarkan tanpa kehadiran ayahnya cenderung mendapat nilai rendah dalam ujian bahasa dan matematika. Ketika menginjak usia 7-10 tahun, anak-anak yang dibesarkan oleh orangtua tunggal cenderung memperoleh nilai-nilai yang lebih rendah, lebih bermasalah dalam hal perilaku, dan sangat cenderung menderita gangguan kesehatan kronis dan gangguan kejiwaan. Di antara anak-anak berusia belasan tahun dan awal dua puluhan yang dibesarkan dalam keluarga tanpa ayah, erat kaitannya dengan meningkatnya risiko kehamilan remaja, putus sekolah sewaktu $S M U$, pemenjaraan, dan pengangguran" (Allene Mamoto, 2015).

Majalah Atlantic Monthly menyimpulkan, "Seperti yang diperlihatkan oleh banyak bukti sosialilmiah, anak-anak dari keluarga bercerai dan anak-anak di luar nikah kurang berhasil dalam beberapa aspek dibandingkan dengan anak-anak dari keluarga yang utuh. Risikonya enam kali lipat bagi anak-anak dari keluarga dengan orang-tua tunggal untuk jatuh miskin. Besar kemungkinan mereka akan terus miskin" (Allene Mamoto,2015).

Dari pernyataan diatas jelas bahwa penelantaran yang dilakukan laki-laki atas hamilnya perempuan di luar kawin mempunyai dampak yang serius bagi anak mereka. Dari sini tampak adanya kekosongan hukum, terdapat suatu peristiwa namun tidak ada norma yang mengaturnya. Padahal negara semestinya harus melindungi segenap warganya dari kemungkinan-kemungkinan buruk yang akan menimpa masyarakatnya.

\section{Perbuatan Laki-laki Menelantarkan Perempuan dan Anak di Luar Kawin Adalah Kejahatan}

Kejahatan atau tindak kriminal merupakan salah satu bentuk dari "perilaku menyimpang" yang selalu ada dan melekat pada tiap bentuk masyarakat, tidak ada masyarakat yang sepi dari kejahatan. Menurut Dr. Saparinah Sadli, perilaku menyimpang itu merupakan suatu ancaman yang nyata atau ancaman terhadap norma-norma sosial yang mendasari kehidupan atau keteraturan sosial, dapat menimbulkan ketegangan individual maupun ketegangan-ketegangan sosial, dan merupakan ancaman riil atau potensial bagi berlangsungnya ketertiban sosial. Dengan demikian kejahatan disamping merupakan masalah kemanusiaan, ia juga merupakan masalah sosial.Terhadap masalah kemanusiaan dan masalah kemasyarakatan yang tertua ini telah banyak usaha-usaha penanggulangan yang dilakukan dalam berbagai cara. Salah satu usaha pencegahan dan pengendalian kejahatan itu ialah menggunakan sanksinya yang berupa pidana (Muladi,1998,148).

Sejarah menunjukkan bahwa berubah dan berkembangnya kejahatan diikuti pula dengan berkembangnya pidana itu sendiri. Sangat tepat pula kiranya apa yang dikemukakan oleh S. Balakrishnan, bahwa "hukum pidana sedang berubah dan memang seharusnya memerlukan perubahan sesuai dengan 
perubahan masyarakat" (Muladi dan Barda Nawawi, 2005,88).

Perbuatan laki-laki menelantarkan perempuan dan anak di luar kawin memanglah dalam masyarakat negara kita merupakan perbuatan yang jahat atau tak dikehendaki masyarakat. Sebagai contoh di masyarakat Bali, dikenal sebuah delik adat yang bernama "Lokika Sanggraha", delik ini diartikan sebagai hubungan percintaan antara seorang laki-laki dengan perempuan dimana keduanya belum terikat suatu perkawinan yang sah menurut hukum nasional maupun hukum adat, laki-laki tersebut berjanji untuk mempersunting si wanita yang ahirnya bersedia menyerahkan kehormatannya namun akhirnya si laki-laki ingkar janji untuk mempersunting wanita tersebut. Delik ini tercantum dalam pasal 359 kitab Adhigama yang saat ini masih berlaku di masyarakat adat bali. Perbuatan ini dianggap sebagai pelanggaran hukum masyarakat dan pelanggaran rasa keadilan dalam masyarakat (Eka Suputra, 2013).

Kehidupan masyarakat, perbuatan menelantarkan perempuan dan anak di luar kawin adalah perbuatan yang dikecam, dibenci, dan akan mendatangkan sanksi social tertentu bagi pembuatnya. Perbuatan tersebut juga mendatangkan kerugian bagi wanita dan anak, bagi wanita tentu saja hal ini membawa pukulan berat karena selain mendapat sanksi sosial dari masyarakat berupa cibiran, kecaman, tentu saja ia harus menerima kenyataan pahit untuk membesarkan anaknya seorang diri. Suatu hal yang tidak mudah, apalagi jika perempuan tersebut tidak atau belum memiliki pekerjaan. Akhirnya, tetap anak lah yang menjadi korban utama. Sejak dalam kandungan, kondisi psikis sang ibu yang merasa tertekan karena larinya ayah dari sang ibu dan anak, tentu mempunyai efek tersendiri bagi janin yang dikandungnya, kemudian setelah bayi lahir, keadaan ekonomi yang menjadi barometer tercukupinya kehidupan sang anak dipertanyakan mengingat bapak yang seharusnya memberi nafkah tidak bertanggung jawab untuk itu. Sehingga sang anak dimungkinkan tidak mendapat penghidupan dan pendidikan yang layak seperti anak dengan kedua orang tua yang masih utuh.

Hal tersebut tentunya sejalan dengan perintah dalam Pasal 26 Undang-undang Republik Indonesia Nomor 35 tahun 2014 Tentang Perubahan atas Undang-undang Nomor 23 Tahun 2002 Tentang Perlindungan Anak yang berbunyi:

(1) Orang tua berkewajiban dan bertanggung jawab untuk:

a. mengasuh, memelihara, mendidik, dan melindungi Anak;

b. menumbuh kembangkan Anak sesuai dengan kemampuan, bakat, dan minatnya;

c. mencegah terjadinya perkawinan pada usia anak; dan

d. memberikan pendidikan karakter dan penanaman nilai budi pekerti pada anak.

Undang-undang memberi kewajiban kepada orang tua untuk mengasuh, memelihara, mendidik dan melindungi anak, sehingga perbuatan seorang ayah yang meninggalkan anaknya walaupun anak tersebut adalah berasal dari hubungan luar kawin, adalah perbuatan yang bertentangan dengan pasal 26 UU Perlindungan anak.

Sekarang mari kita cermati Pasal 1 UU Perlindungan anak:

Undang-Undang ini yang dimaksud dengan:

1. Anak adalah seseorang yang belum berusia 18 (delapan belas) tahun, termasuk anak yang masih dalam kandungan;

2. Perlindungan anak adalah segala kegiatan untuk menjamin dan melindungi anak dan hakhaknya agar dapat hidup, tumbuh, berkembang, dan berpartisipasi secara optimal sesuai dengan harkat dan martabat dan martabat kemanusiaan, serta mendapat perlindungan dari kekerasan dan diskriminasi; 
3. Keluarga adalah unit terkecil dalam masyarakat yang terdiri atas suami istri, atau suami istri dan anaknya, atau ayah dan anaknya, atau ibu dan anaknya, atau keluarga sedarah dalam garis lurus ke atas atau ke bawah sampai dengan derajat ketiga;

4. Orang Tua adalah ayah dan/atau ibu kandung, atau ayah dan/atau ibu tiri, atau ayah dan/ atau ibu angkat.

Jika kita mencermati pasal 1, terminologi anak diartikan "seseorang yang belum berusia 18 tahun, termasuk anak yang masih dalam kandungan", jadi dapat disimpulkan bahwa seseorang tidak peduli hasil dari pernikahan sah atau hasil dari hubungan luar kawin yang mana ia belum berusia 18 tahun atau masih dalam kandungan ialah seorang anak yang dilindungi dalam undang-undang ini. Jadi tidak ada perbedaan anak luar kawin atau anak dari pernikahan sah untuk mendapatkan hakhaknya, negara melindungi semua anak apapun statusnya dengan porsi yang sama, tidak membedabedakan sama sekali.

Jika kita melihat terminologi orang tua dalam poin 4, disebutkan bahwa orang tua adalah ayah dan atau ibu kandung, tidak ada syarat lain, apakah ayah atau ibu kandung tersebut mempunyai hubungan suami istri yang sah atau tidak, tetap ia adalah orang tua, cukup dengan syarat mereka adalah bapak/ibu kandung dari anak tersebut. sehingga tidak ada alasan bagi orang tua, walaupun mereka tidak terikat perkawinan yang sah, untuk tidak memberikan hak-hak seorang anak, karena negara memberikan perintah bagi bapak dan atau ibu kandung dari anak ini untuk memberikan hak anak dengan sebaik-baiknya.

Kemudian kita cermati Pasal 23 UU Perlindungan anak yang berbunyi sebagai berikut:

“(1) Negara, Pemerintah, dan Pemerintah Daerah menjamin perlindungan, pemeliharaan, dan kesejahteraan Anak dengan memperhatikan hak dan kewajiban Orang
Tua, Wali, atau orang lain yang secara hukum bertanggung jawab terhadap Anak."

Pasal tersebut jelas bahwa negara menjamin perlindugan anak dengan memperhatikan hak dan kewajiban orang tua, namun menurut hemat penulis tidak ada perlindungan negara terhadap pemenuhan hak anak hasil hubungan luar kawin, yang mana dapat dilihat tidak ada sanksi yang diberikan kepada orang tua yang tidak memberikan hak anak dan tidak melaksanakan kewajibannya sebagai orang tua. Jika seorang anak tersebut adalah anak dari pernikahan yang sah tentu ia sudah mendapat perlindungan dari undangundang Pasal 49 Undang-undang Republik Indonesia Nomor 23 tahun 2004 Tentang Penghapusan Kekerasan dalam Rumah Tangga yang berbunyi:

"Dipidana dengan pidana penjara paling lama 3 (tiga) tahun atau denda paling banyak Rp 15.000.000,00 (lima belas juta rupiah), setiap orang yang:

a. menelantarkan orang lain dalam lingkup rumah tangganya sebagaimana dimaksud dalam Pasal 9 ayat (1);

b. menelantarkan orang lain sebagaimana dimaksud Pasal 9 ayat (2)."

Namun bagaimana dengan anak dari hubungan luar kawin?

Pasal 76B UU Perlindungan anak disebutkan "Setiap orang dilarang menempatkan, membiarkan, menyuruh melibatkan anak dalam situasi perlakuan salah dan penelantaran".

Pasal ini mengandung makna yang tidak jelas, dan menimbulkan beragam penafsiran. Apakah penelantaran disini dapat dikategorikan sama dengan penelantaran sebagaimana dimaksud dalam Undang-undang tentang Penghapusan kekerasan dalam rumah tangga, atau kah dimaknai lain. Sedangkan dalam penjelasan pasal dinyatakan cukup jelas sehingga maksud pasal ini sulit untuk diartikan maknanya. Jika penelantaran dimaksud dengan penelantaran dengan meninggalkan anak 
dengan tidak mengindahkan hak-hak yang seharusnya ia terima maka berbenturan dengan kata sebelumnya yang berbunyi "menyuruh melibatkan anak", karena jika penelantaran yang dimaksud adalah seperti hal yang diatas, maka tidak mungkin anak disuruh melibatkan dirinya dalam penelantarannya sendiri. Pasal ini sungguh rancu sehingga akan sulit untuk diterapkan. Sehingga menurut penulis, dalam undang-undang perlindungan anak belum ada aturan yang melindungi anak luar kawin dari tidak dilaksanakannya kewajiban-kewajiban dari orang tua anak tersebut. kedepan seharusnya pasal ini diperjelas atau dibuat sebuah aturan baru yang mengakomodir perbuatan ini.

KUHP nasional kita tidak mengakomodir perbuatan ini secara jelas di dalamnya, sehingga sampai saat ini perbuatan laki-laki menelantarkan wanita dan anak di luar kawin bukan merupakan perbuatan yang jahat menurut KUHP. Namun jika kita menilik ke Bab XV KUHP Pasal 304 menyatakan "Barang siapa dengan sengaja menempatkan atau membiarkan seorang dalam keadaan sengsara, padahal menurut hukum yang berlaku baginya atau karena persetujuan dia wajib memberi kehidupan, perawatan atau pemeliharaan kepada orang itu, diancam dengan pidana penjara paling lama dua tahun delapan bulan atau pidana denda paling banyak empat ribu lima ratus rupiah".

R. Soesilo dalam buku Kitab undang-undang Hukum Pidana serta komentarnya Lengkap Pasal Demi Pasal menyatakan yang dihukum menurut Pasal 304 KUHP adalah orang yang sengaja menyebabkan atau membiarkan orang lain dalam kesengsaraan, sedang ia wajib memberi kehidupan, perawatan atau pemeliharaan kepada orang itu karena hukum yang berlaku atau karena perjanjian. Misalnya orang tua membiarkan anaknya dalam keadaan sengsara, demikian pula wali terhadap anak yang diasuhnya. Sedangkan orang kaya membiarkan saudara kandungnya dalam sengsara, tidak dikenakan pasal ini, karena menurut hukum ia tidak diwajibkan untuk menyokongnya.
Penjelasan Soesilo orang tua membiarkan anaknya sengsara adalah masuk dalam unsur pasal ini, orang tua dalam anggapan umum adalah suami istri yang terikat perkawinan dan dalam perkawinan tersebut memiliki seorang anak. Namun bagaimana dengan mereka yang tidak terikat perkawinan dan memiliki seorang anak?apakah kemudian penelantaran terhadapnya tidak dapat masuk dalam rumusan ini?

Undang-Undang Perlindungan Anak pengertian orang tua adalah ayah dan/atau ibu kandung, atau ayah dan/atau ibu tiri, atau ayah dan/atau ibu angkat. Tidak ada penambahan makna dari perkawinan yang sah, namun anggapan umum yang ada dalam masyarakat mengartikan orang tua adalah mereka yang sudah terikat perkawinan yang sah.

Menurut analisa penulis, pasal ini tidak dapat mengakomodasi wanita sebagai orang yang dibuat sengsara dalam pasal ini, karena disebut kemudian "padahal menurut hukum yang berlaku baginya atau karena persetujuan dia wajib memberi kehidupan, perawatan atau pemeliharaan kepada orang itu", lakilaki dan wanita yang belum kawin tidak terikat oleh hukum sehingga tidak menimbulkan hak dan kewajiban tertentu bagi masing-masing, sehingga tidak termasuk dalam unsur pasal ini. Namun anak yang sedang dikandung atau telah dilahirkan walaupun di luar kawin secara hukum telah menimbulkan kewajiban hukum bagi orang tuanya sebagaimana dimaksud dalam undang-undang perlindungan anak. Anak yang masih dalam kandungan pun termasuk pengertian anak yang dilindungi sebagaimana pengertiannya dalam UndangUndang Perlindungan Anak "Anak adalah seseorang yang belum berusia 18 (delapan belas) tahun, termasuk anak yang masih dalam kandungan".

Namun tentunya sulit untuk menerapkannya dalam praktek, penegak hukum akan cenderung mengembalikan laporan adanya penelantaran wanita atau anak di luar kawin, daripada harus mengkontruksikan perbuatan tersebut ke dalam 
pasal dalam KUHP karena adanya asas legalitas dalam KUHP yang harus diterapkan secara ketat.

Padahal menurut beberapa ahli hukum, bahkan hukum pidanapun semestinya tidak terlepas dari penemuan hukum. "Every legal norm needs interpretation", demikian pernyataan Matchteld Boot yang berati bahwa setiap norma hukum membutuhkan interpretasi. Senada dengan Boot adalah Van Bemmelen dan Van Hattum yang secara tegas menyatakan "Elke geschreven wetgeving behoeft interpretative" (setiap aturan perundang-undangan tertulis membutuhkan interpretasi). Demikian pula Remmelink yang berpendapat bahwa sekalipun rangkaian kata-kata yang ditemukan dalam hukum pidana, pakar hukum pidana, terutama hakim pidana, tidak mungkin menerapkan perundangundangan tanpa menggunakan penafsiran. (Eddys O.S. Hiariej, 2009, 65).

Sehingga untuk menemukan solusi kiranya dapat atau tidak perbuatan ini masuk dalam unsur pasal 304 KUHP dibutuhkan penafsiran hukum. Secara garis besar ada empat metode penafsiran yang umum dan sering digunakan. Pertama interpretasi gramatik, interpretasi sistematis atau logis, intrepretasi historis, dan keempat interpretasi telelogis atau sosiologis. Selanjutnya untuk analogi dibedakan menjadi dua, yaitu argumentum peranalogiam atau sering disebut analogi dan $\operatorname{argu-}$ mentum a contrario. Perihal analogi, disini suatu peraturan khusus dalam undang-undang dijadikan umum yang tidak tertulis dalam undang-undang, kemudian digali asas yang terdapat di dalamnya dan disimpulkan dari ketentuan umum itu suatu peristiwa yang khusus. Sedangkan argumentum a contrario adalah penafsiran yang didasarkan pada pengertian sebaliknya dari peristiwa konkret yang dihadapi dengan peristiwa yang diatur dalam undang-undang (Eddy O.S. Hiariej, 2009,70).

Konteks hukum pidana, pertanyaan selanjutnya adalah boleh atau tidaknya analogi diterapkan. Apabila kita bertumpu pada asas legalitas dengan salah satu makna yang terkandung di- dalamnya nullum crimen, noela poena sine lege stricta, secara implisit analogi tidak diperbolehkan. Arti nullum crimen, noela poena sine lege stricta, seperti yang telah diutarakan diatas adalah bahwa ketentuan pidana harus ditafsirkan secara ketat sehingga tidak menimbulkan tindak pidana baru.

Menurut pendapat penulis, solusi dalam waktu dekat untuk mengakomodasi kekosongan hukum atas seringnya terjadi peristiwa yang serupa dalam masyarakat, adalah kiranya dipikirkan untuk memasukkan perbuatan laki-laki menelantarkan wanita dan anak di luar kawin termasuk dalam Pasal 304 KUHP, karena dalam pasal tersebut sudah jelas dinyatakan "barang siapa", sehingga tidak terikat subyek hukum tertentu, jadi bisa untuk siapa saja, kemudian "dengan sengaja menempatkan atau membiarkan seorang dalam keadaan sengsara", perbuatan laki-laki menelantarkan wanita dan anak di luar kawin tentu saja termasuk menempatkan atau membiarkan seorang dalam keadaan sengsara, karena wanita dalam hal ini dibiarkan untuk menanggung beban kehamilannya seorang diri dan ketika sang anak lahir ia pun harus sengsara untuk merawat anak sendirian sekaligus mencarikan nafkah untuk anak tersebut, menurut hukum sang laki-laki memang wajib memberi kehidupan, perawatan, dan pemeliharaan. Namun kedepannya tentu saja harus ada aturan hukum baru yang jelas mengatur tentang perbuatan penelantaran terhadap wanita dan anak di luar kawin ini.

\section{Kriminalisasi dalam Kebijakan Hukum Pidana}

Jika kita telah menyetujui bahwa perbuatan penelantaran di atas adalah termasuk perbuatan jahat, agar terbentuk suatu aturan yang jelas dan lengkap maka berikutnya adalah kewenangan dari kebijakan hukum pidana yang akan berbicara.

Istilah kebijakan berasal dari bahasa Inggris yakni Policy atau dalam bahasa Belanda Politiek yang secara umum dapat diartikan sebagai prinsip- 
prinsip umum yang berfungsi untuk mengarahkan pemerintah dalam arti luas termasuk pula aparat penegak hukum dalam mengelola, mengatur, atau menyelesaikan urusan-urusan publik, masalahmasalah masyarakat atau bidang-bidang penyusunan peraturan perundang-undangan dan pengaplikasian hukum/peraturan, dengan tujuan (umum) yang mengarah pada upaya mewujudkan kesejahteraan atau kemakmuran masyarakat (warga negara) (Barda Nawawi Arif, 2010, 23).

Bertolak dari kedua istilah asing tersebut, maka istilah kebijakan hukum pidana dapat pula disebut dengan istilah politik hukum pidana. Dalam kepustakaan asing istilah politik hukum pidana ini sering dikenal dengan berbagai istilah, antara lain penal policy, criminal law policy atau staftrechtspolitiek (Aloysius Wisnusubroto, 1999,10).

Selanjutnya, A.Mulder mengemukakan bahwa kebijakan hukum pidana ialah garis kebijakan untuk menentukan (Aloysius, 1999, 12):

1. Seberapa jauh ketentuan-ketentuan pidana yang berlaku perlu diubah atau diperbaharui;

2. Apa yang dapat diperbuat untuk mencegah terjadinya tindak pidana;

3. Cara bagaimana penyidikan, penuntutan, peradilan dan pelaksanaan pidana harus dilaksanakan.

Dilihat dari perspektif hukum pidana, maka kebijakan formulasi harus memperhatikan harmonisasi internal dengan sistem hukum pidana atau aturan pemidanaan umum yang berlaku saat ini. Tidaklah dapat dikatakan terjadi harmonisasi/ sinkronisasi apabila kebijakan formulasi berada di luar sistem hukum pidana yang berlaku saat ini. Kebijakan formulasi merupakan tahapan yang paling stategis dari penal policy karena pada tahapan tersebut legislatif berwenang dalam hal menetapkan atau merumuskan perbuatan apa yang dapat dipidana yang berorientasi pada permasalahan pokok hukum pidana meliputi perbuatan yang bersifat melawan hukum, kesalahan, pertanggung jawaban pidana dan sanksi apa yang dapat dikenakan. Oleh karena itu, upaya penanggulangan kejahatan bukan hanya tugas aparat penegak hukum tetapi juga tugas aparat pembuat undangundang (aparat legislatif) (Aloysius, 1999,12).

Perencanaan (planning) pada tahapan formulasi pada intinya, menurut Nils Jareborg mencakup tiga masalah pokok struktur hukum pidana, yaitu masalah (Nila Jareborg, 2010, 81):

1. Perumusan tindak pidana/kriminalisasi dan pidana yang diancamkan (criminalization and threatened punishment);

2. Pemidanaan (adjudication of punishment sentencing);

3. Pelaksanaan pidana (execution of punishment).

Berkaitan dengan kebijakan kriminalisasi, menurut Sudarto bahwa perlu diperhatikan halhal yang intinya sebagai berikut (Sudarto, 1983, 23):

1. Penggunaan hukum pidana harus memperhatikan tujuan pembangunan nasional, yaitu mewujudkan masyarakat adil makmur yang merata materiil dan spiritual berdasarkan dengan Pancasila, sehubungan dengan ini (penggunaan) hukum pidana bertujuan untuk menanggulangi kejahatan dan mengadakan upaya penggugatan terhadap tindakan penanggulangan itu sendiri demi kesejahteraan dan pengayoman masyarakat;

2. Perbuatan yang diusahakan untuk dicegah atau ditanggulangi dengan hukum pidana harus merupakan perbuatan yang tidak dikehendaki yaitu perbuatan yang mendatangkan kerugian (materiil dan sprituil) atas warga masyarakat;

3. Penggunaan hukum pidana harus pula memperhitungkan prinsip biaya dan hasil (cost and benefit principle);

4. Penggunanan hukum pidana harus pula memperhatikan kapasitas atau kemampuan daya kerja dari badan-badan penegak hukumya itu jaringan sampai ada kelampauan beban tugas (overbelasting). 
Sejalan dengan yang dikemukakan Sudarto di atas, menurut Bassiouni bahwa keputusan untuk melakukan kriminalisasi dan dekriminilisasi harus didasarkan pada faktor-faktor kebijakan tertentu yang mempertimbangkan bermacam-macam faktor, termasuk (Muladi dan Barda Nawawi, 1998, 166):

1. Keseimbangan sarana-sarana yang digunakan dalam hubungannya dengan hasil-hasil yang ingin dicapai;

2. Analisis biaya terhadap hasil-hasil yang diperoleh dalam hubungannya dengan tujuantujuan yang dicari;

3. Penilaian atau penafsiran tujuan-tujuan yang dicari itu dalam kaitannya dengan prioritasprioritas lainnya dalam pengalokasian sumbersumber tenaga manusia;

4. Pengaruh sosial dari kriminalisasi dan dekriminalisasi yang berkenaan dengan atau dipandang dari pengaruh-pengaruh yang sekunder.

Hal lain yang perlu dikemukakan dari pendekatan kebijakan adalah yang berkaitan dengan nilai-nilai yang ingin dicapai atau dilindungi oleh hukum pidana. Menurut Bassiouni, tujuan-tujuan yang ingin dicapai oleh pidana pada umumnya terwujud dalam kepentingan-kepentingan sosial yang mengandung nilai-nilai tertentu yang perlu dilindungi. Kepentingan-kepentingan sosial tersebut adalah (Muladi dan Barda Nawawi, 1998,167):

1. Pemeliharaan tertib masyarakat;

2. Perlindungan warga masyarakat dari kejahatan, kerugian atau bahaya-bahaya yang tidak dapat dibenarkan, yang dilakukan oleh orang lain;

3. Memasyarakatkan kembali (rasionalisasi) para pelanggar hukum;

4. Memelihara atau mempertahankan integritas pandangan-pandangan dasar tertentu mengenai keadilan sosial, martabat kemanusian dan keadilan individu.
Berdasarkan pertimbangan di atas, dapat disimpulkan bahwa syarat kriminalisasi pada umumnya adalah:

1. Adanya korban;

2. Kriminalisasi bukan semata-mata ditujukan untuk pembalasan;

3. Harus berdasarkan asas ratio-principle; dan

4. Adanya kesepakatan sosial (public support).

Selanjutnya, untuk merumuskan suatu perbuatan menjadi perbuatan yang dilarang oleh hukum pidana, harus mempertimbangkan hal-hal sebagai berikut (Teguh Prasetyo dan Abdul Halim Barkatullah, 2005, 51):

1. Perbuatan tersebut haruslah benar-benar perbuatan yang jahat atau tidak dikehendaki oleh masyarakat atau merugikan masyarakat. Dengan kata lain jahat berarti merugikan atau menyerang kepentingan hukum (baik kepentingan hukum individu, masyarakat maupun kepentingan hukum negara);

2. Diperhatikan pula kesiapan aparatur penegak hukum dalam menegakkan hukum pidana itu nantinya, baik itu kesiapan secara kualitatif yang menyangkut profesionalisme aparatur, maupun dari segi kuantitatif, yakni apakah seimbang dengan kuantitas aparat sehingga tidak menjadi beban baginya;

3. Diperhatikan pula cost and benefit principle, artinya biaya pembuatan suat peraturan pidana harus benar-benar diperhitungkan apakah sudah sesuai dengan tujuan dibentuknya peraturan pidana, atau apakah sudah tersedia biaya yang memadai dalam penegakan hukum itu nantinya, sebab ketidaksiapan biaya penegakan hukum (termasuk pengadaan sarana dan prasarananya) justru akan menyakiti masyarakat.

Kebijakan hukum pidana berkaitan dengan masalah kriminalisasi yaitu perbuatan apa yang dijadikan tindak pidana dan penalisasi yaitu sanksi 
apa yang sebaiknya dikenakan pada si pelaku tindak pidana. Kriminalisasi dan penaliasi menjadi masalah sentral yang untuk penanganannya diperlukan pendekatan yang berorientasi pada kebijakan (policy oriented approach). Kriminalisasi (criminalisation) mencakup lingkup perbuatan melawan hukum (actus reus), pertanggungjawaban pidana (mens rea) maupun sanksi yang dapat dijatuhkan baik berupa pidana (punishment) maupun tindakan (treatment). Kriminalisasi harus dilakukan secara hati-hati, jangan sampai menimbulkan kesan represif yang melanggar prinsip ultimum remedium (ultima ratio principle) dan menjadi bumerang dalam kehidupan sosial berupa kriminalisasi yang berlebihan (oever criminalisation), yang justru mengurangi wibawa hukum. Kriminalisasi dalam hukum pidana materiil akan diikuti pula oleh langkah-langkah pragmatis dalam hukum pidana formil untuk kepentingan penyidikan dan penuntutan (Muladi, 2003, 1).

\section{PENUTUP}

Perbuatan laki-laki menelantarakan wanita dan anak di luar kawin adalah suatu perbuatan yang seharusnya dikategorikan sebagai perbuatan jahat dan patut dipidana, karena perbuatan ini bertetangan dengan nilai-nilai yang ada dalam masyrakat, dan perbuatan ini mendatangkan kerugian secara materiil maupun immateriil bagi wanita dan anak.

Perbuatan ini pun tidak sesuai dengan prinsip-prinsip yang ada dalam Undang-undang Undang-undang Republik Indonesia Nomor 35 tahun 2014 Tentang Perubahan atas UndangUndang Nomor 23 Tahun 2002 tentang perlindungan anak sehingga sudah sepatutnya perbuatan ini dilgolongkan sebagai tindak pidana.

\section{DAFTAR PUSTAKA}

Buku

Arief, Barda Nawawi, 2010, Bunga Rampai Kebijakan Hukum Pidana, PT. Citra Aditya Bakti, Bandung.

Arif,Barda Nawawi, 2007, Masalah Penegakan Hukum dan Kebijakan Hukum Pidana dalam Penanggulangan Kejahatan, Kencana Media Group, Jakarta.

Muladi dan Arief, Barda Nawawi, 1998, Teori-Teori dan Kebijakan Pidana, Cet II, Alumni, Bandung.

Hiariej, Edy, 2009. Asas Legalitas dan Penemuan Hukum Dalam Hukum Pidana. Erlangga, Jakarta.

Muladi, 2003, Kebijakan Kriminal terhadap Cybercrime, Majalah Media Hukum Vol. 1 No. 3 tanggal 22 Agustus.

Prasetyo, Teguh dan Barkatullah, Abdul Halim, 2005, Politik Hukum Pidana: Kajian Kebijakan Kriminalisasi dan Dekriminilisasi, Pustaka Pelajar, Yogyakarta.

Prasetyo, Teguh, 2011, Kriminalisasi dalam Hukum Pidana, Nusa Media, Jakarta.

\section{Artikel dari Internet}

Mamoto, Allene.Minggat Setelah Menghamili Segampang itukah?, www.yayasanembunsurabaya. blogspot.co.id., (diakses pada tanggal 25 Mei 2017).

Anonim, 63-persen-remaja-di-indonesia-melakukan-seks-pranikah, www.kompasiana.com., (diakes pada tanggal 30 Mei 2017).

Hadinata,Welly,Pacarnya Dihamili Tapi Tak Mau Bertanggungjawab, Alasan Pria Ini Bikin Gregetan, www.bangka.tribunnews.com., (diakes pada tanggal 30 Mei 2017).

\section{Peraturan Perundang-undangan}

Undang-Undang Republik Indonesia Nomor 35 Tahun 2014 Tentang Perubahan atas Undang-Undang Nomor: 23 Tahun 2002 Tentang Perlindungan Anak. 